\title{
Review of the Orphninae (Coleoptera: Scarabaeidae) of Sri Lanka, with description of a new species of genus Orphnus Macleay, 1819
}

\author{
Andrey V. FROLOV ${ }^{\circledR 1, *}$ \& Lilia A. AKHMETOVA ${ }^{\circledR} 2$ \\ ${ }^{1,2}$ Laboratory of Insect Systematics, Zoological Institute, Russian Academy of Sciences, \\ Universitetskaya nab., 1, St.-Petersburg, 199034 Russia. \\ *Corresponding author: frolov@scarabaeoidea.com \\ 2Email: akhmetova@scarabaeoidea.com \\ ${ }^{1}$ urn:lsid:zoobank.org:author:5DEE612B-4252-4DB0-AD5E-BAA789A3C355 \\ ${ }^{2}$ urn:lsid:zoobank.org:author:BA35DDDD-6E6A-47A4-AB73-965EB4A92CC3
}

\begin{abstract}
The scarab beetles of the subfamily Orphninae (Coleoptera: Scarabaeidae) from Sri Lanka are reviewed. Four species of the genus Orphnus Macleay, 1819, are recorded from the island: O. bicolor (Fabricius, 1801), O. parvus (Wiedemann, 1823), O. mysoriensis Westwood, 1845, and O. medvedevi sp. nov. Lectotypes are designated for the three former names. Synonymy of $O$. detegens Walker, 1859 , and O. scitissimus Walker, 1859, is discussed. Keys, illustrations of habitus and male genitalia, and distributional record maps are given for all species.
\end{abstract}

Keywords. Scarab beetles, Orphnines, Southeastern Asia, Ceylon.

Frolov A.V. \& Akhmetova L.A. 2021. Review of the Orphninae (Coleoptera: Scarabaeidae) of Sri Lanka, with description of a new species of genus Orphnus Macleay, 1819. European Journal of Taxonomy 767: 40-54. https://doi.org/10.5852/ejt.2021.767.1485

\section{Introduction}

Scarab beetles of the subfamily Orphninae Erichson, 1847, are mostly distributed in the southern continents. The nominative and most speciose genus of this subfamily, Orphnus Macleay, 1819, has its centre of diversity in the Afrotropics. However, six nominal species including the type species of the genus, O. bicolor (Fabricius, 1801), are known from Southeast Asia including the island of Sri Lanka. Three species of Orphnus have been described from Sri Lanka: O. nanus Westwood, 1845, O. detegens Walker, 1859, and O. scitissimus Walker, 1859. Later, Arrow (1912) suggested that all these names are synonyms of two Indian species, O. parvus (Wiedemann, 1823) (the former name) and O. mysoriensis Westwood, 1845 (the two latter names).

The literature on Asian Orphninae is limited to primary sources with brief diagnoses of the species and catalogues, and provides a poor foundation for species identification. The shape of the aedeagi and internal sac armature, the most reliable diagnostic characters in Orphninae, were not described or illustrated by past authors. 
Reasonable material on Orphninae from Sri Lanka had been accumulated in museums but has never been taxonomically examined. In this material, we recognized four species based on the external morphology and morphology of the male genitalia. Because of the inadequate original descriptions, it was necessary to compare this material with primary types. As a result, we found that the island is inhabited by four species, including two species not recorded from Sri Lanka before: $O$. bicolor and an undescribed species, a putative endemic of the island. The aim of the present contribution is to provide a taxonomic revision of the Orphninae from Sri Lanka, including lectotype designations for published names, description of the new species, re-evaluation of the synonymies proposed by Arrow, detailed illustrations of the male genitalia of all species, as well as a key to species and distribution maps.

\section{Material and methods}

Morphological terminology follows Frolov et al. (2016). Preparation of specimens, digital images, and locality map follow Frolov et al. (2017). Labels of the type specimens are cited verbatim with separate labels separated by a slash '/.

The material used in this work is deposited in the following organisations:

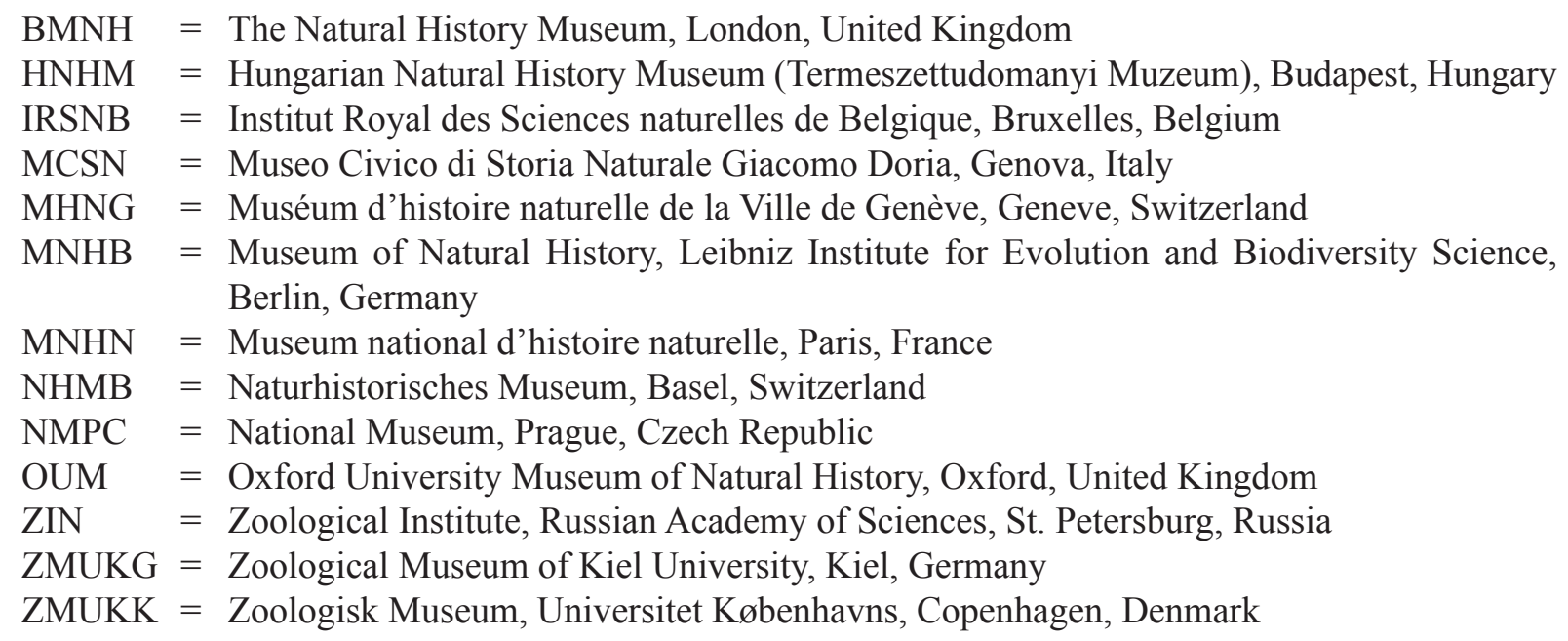

\section{Results}

\section{Taxonomic treatments}

Class Insecta Linneaus, 1758

Order Coleoptera Linnaeus, 1758

Family Scarabaeidae Latreille, 1802

Subfamily Orphninae Erichson, 1847

Genus Orphnus Macleay, 1819

Orphnus mysoriensis Westwood, 1845

Figs 1-2

Orphnus mysoriensis Westwood, 1845: 176.

Orphnus detegens Walker, 1859a: 54 (synonymy by Arrow 1912).

Orphnus scitissimus Walker, 1859b: 220 (synonymy by Arrow 1912).

Orphnus mysoriensis - Lacordaire 1856: 130 (catalogue). — Gemminger \& Harold 1869: 1073 (catalogue). — Arrow 1912: 29 (catalogue, synonymy). — Schmidt 1913: 80 (catalogue). — Mittal 
2005: 46 (catalogue). - Frolov 2012: 794 (catalogue). — Khaustov \& Frolov 2018: 182 (host of Trochometridium tribulatum Cross, 1965).

Orphnus detegens - Preudhomme de Borre 1886: 26 (catalogue).

Orphnus scitissimus - Preudhomme de Borre 1886: 26 (catalogue).

\section{Differential diagnosis}

Orphnus mysoriensis is similar to O. medvedevi sp. nov. in having the pronotum with a more or less developed tubercle on the base medially and the endophallus with one group of spinules. It differs from the latter in body length $(8.0-10.0 \mathrm{~mm}$, as opposed to $4.6-6.0 \mathrm{~mm}$ in $O$. medvedevi sp. nov.), spinules of endophallus as a rather dispersed group of more than 10 spinules (as opposed to a compact cluster consisting of less than 10 spinules in $O$. medvedevi sp. nov., Fig. $1 \mathrm{G}$ vs Fig. 3G), and tubercle on the base of pronotum normally with two punctures (as opposed to always smooth tubercle in $O$. medvedevi sp. nov.).

\section{Type material of Orphnus mysoriensis}

Lectotype (here designated, Fig. 1A-E, G) INDIA - O'; "Mysore / Orphnus mysoriensis Westw / TYPE WESTWOOD Trans. Ent. Soc. 4. 1846. P.176. Coll. Hope Oxon. / TYPE COL: 484 1/3 Orphnus mysoriensis Westw. HOPE DEPT.OXFORD”; OUM.

\section{Paralectotypes}

INDIA • 1 O̊; "Mysore / TYPE COL: 484 2/3 Aegidium mysoriensis Westw. HOPE DEPT.OXFORD"; OUM • 1 q; "Mysore / TYPE COL: 484 3/3 Aegidium mysoriensis Westw. HOPE DEPT.OXFORD"; OUM.

\section{Type material of Orphnus detegens}

Lectotype (here designated, Fig. 2E-G)

SRI LANKA - O'; "Type / Ceylon 59106 / Orphnus detegens Walker. a.n.H. (type) / detegens Wlk"; BMNH.

\section{Additional material examined}

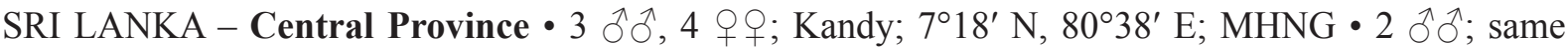
locality data as for preceding; MNHB $\bullet 7 \widehat{\widehat{\jmath}}$; same locality data as for preceding; 1-18 Apr. 1991; Jiri Kolibac leg.; NHMB • 1 q; same locality data as for preceding; 18 Mar. 1973; G. Zimmermann leg.;

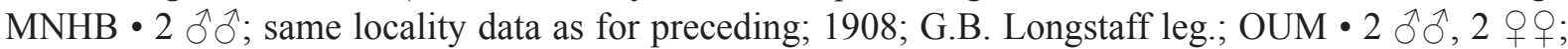
Nalanda; $7^{\circ} 40^{\prime}$ N, $80^{\circ} 39^{\prime}$ E; V. De Poll leg.; MNHN • 1 o ; same locality data as for preceding; 1889;

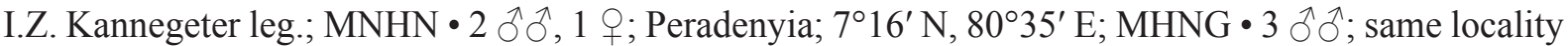
data as for preceding; Friederichs S.G. leg.; MNHB $\bullet 2$ क 1907; O. John leg.; ZIN • 1 đ̇; same locality data as for preceding; 3 Apr. 1907; O. John leg.; ZIN •

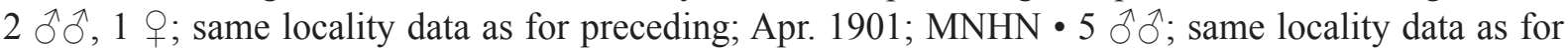
preceding; Apr. 1914; Friederichs S.G. leg.; MNHB 2 2 0 ; same locality data as for preceding; Apr.

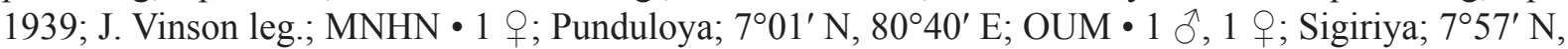

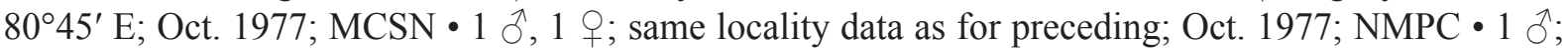
Weragamtota; $7^{\circ} 19^{\prime}$ N, $80^{\circ} 59^{\prime}$ E; 13 Sep. 1953; F. Keiser leg.; NHMB. - North Central Province •

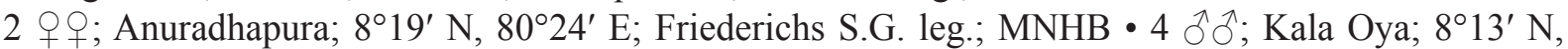
$80^{\circ} 06^{\prime}$ E; 7 Nov. 1983; MNHN - 1 ' ; same locality data as for preceding; 8 Nov. 1983; MNHN •

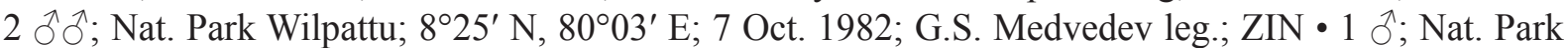
Wilpattu, Talawila; $8^{\circ} 25^{\prime}$ N, $80^{\circ} 03^{\prime}$ E; 9 Oct. 1982; G.S. Medvedev leg.; ZIN ・ 1 ô, 3 o o ; Wilpattu N.P. 17 km WNW entrance Tala Wila; $8^{\circ} 25^{\prime}$ N, 8003' E; 8 Oct. 1982; V.F. Zaitzev leg.; ZIN. - North 

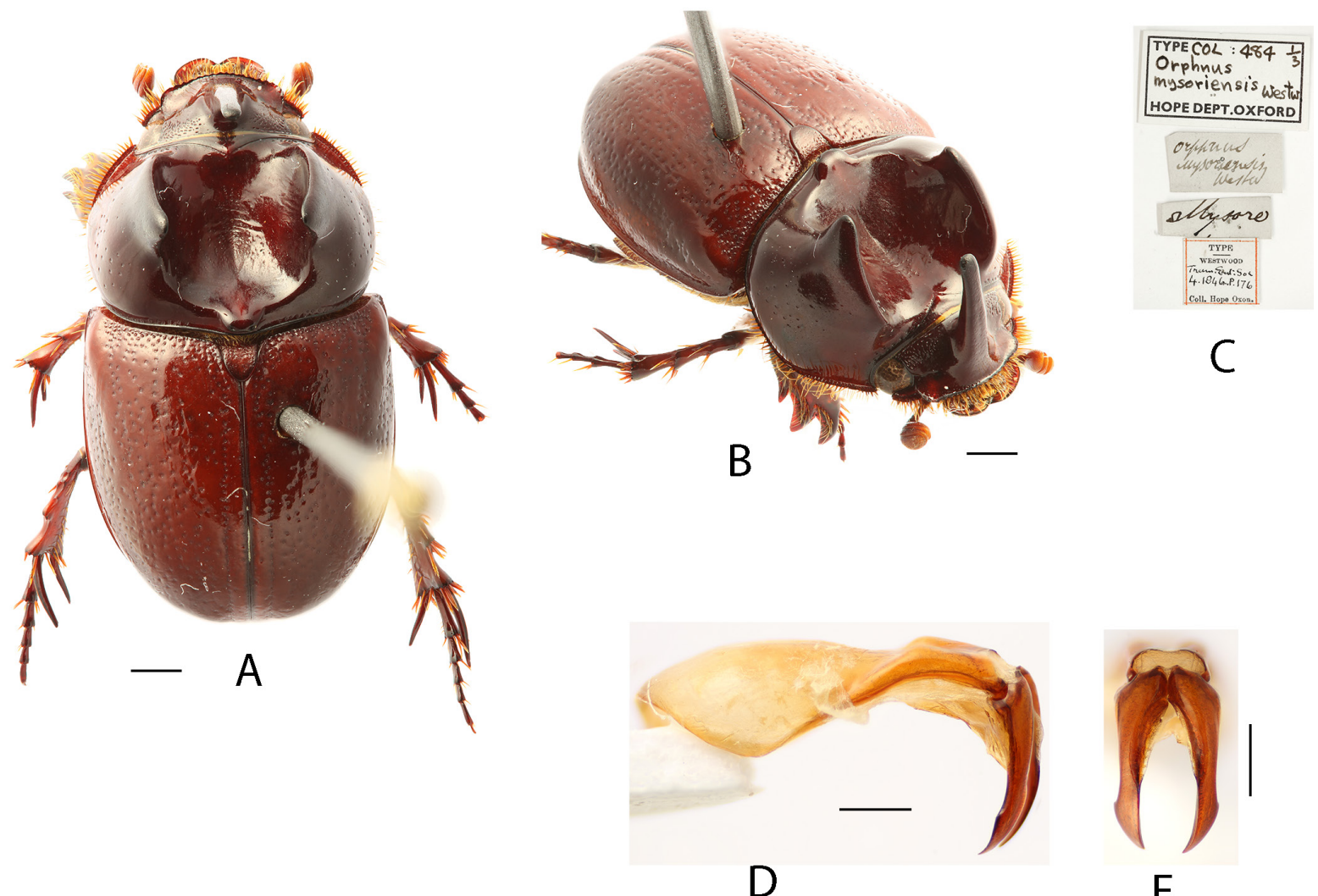

$\mathrm{E}$
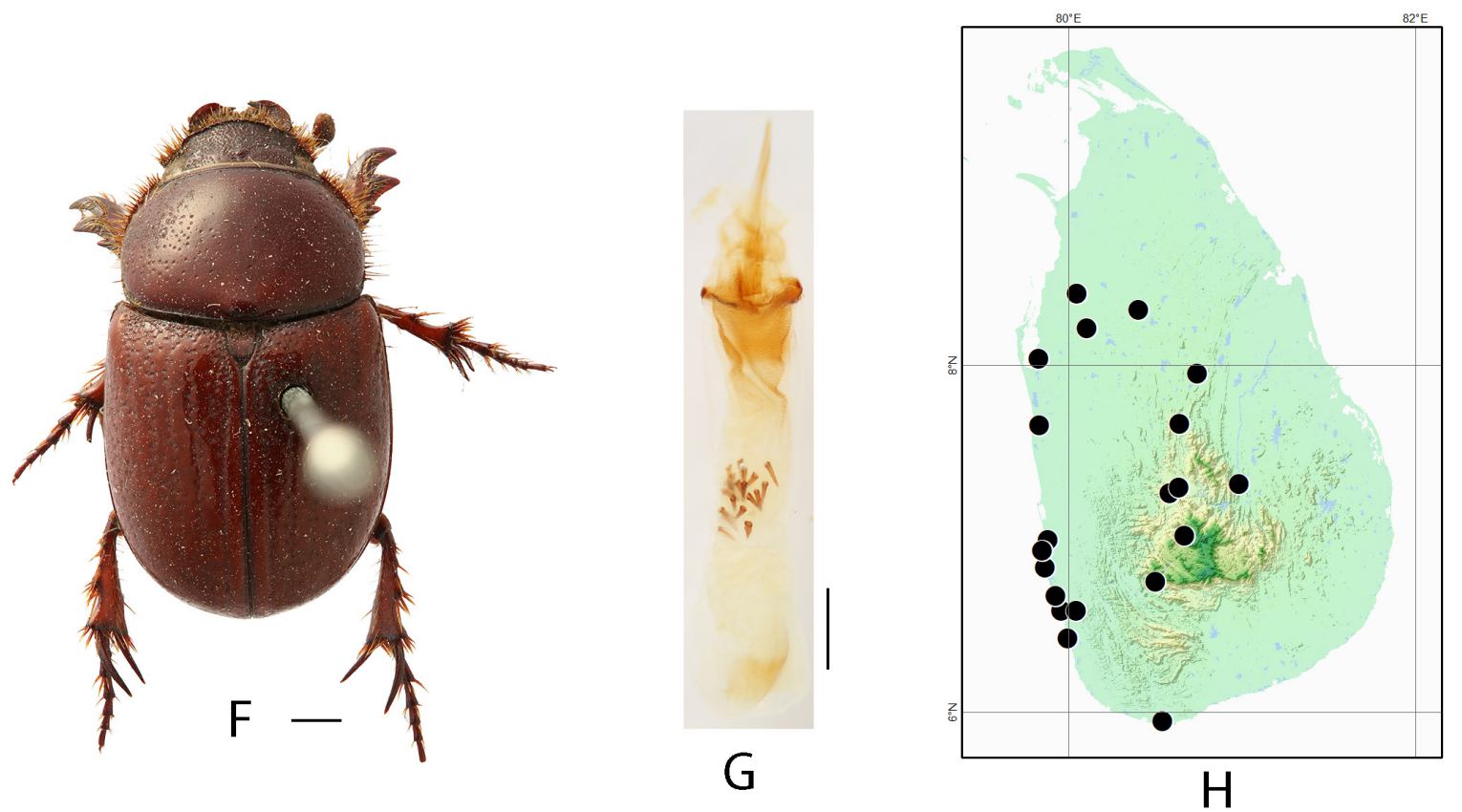

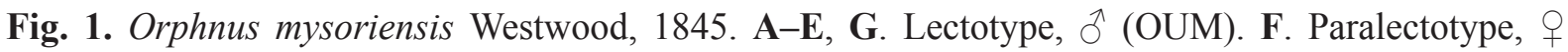
(OUM). A-B, F. Habitus in dorsal view. C. Labels. D. Aedeagus in lateral view. E. Parameres in dorsal view. G. Endophallus. H. Distributional record map. Scale bars: A-B, F $=1.0 \mathrm{~mm}$; D-E, G $=0.5 \mathrm{~mm}$. 


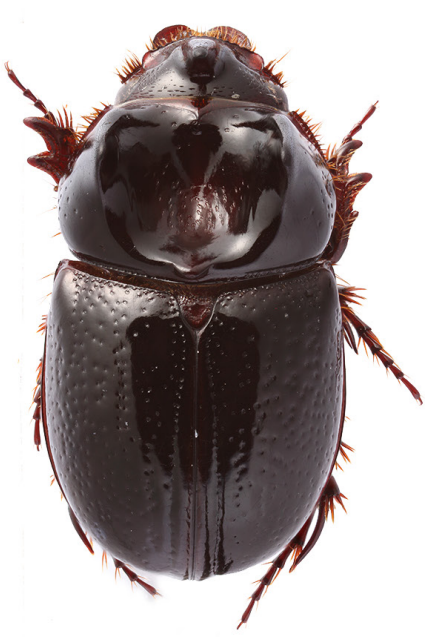

A -
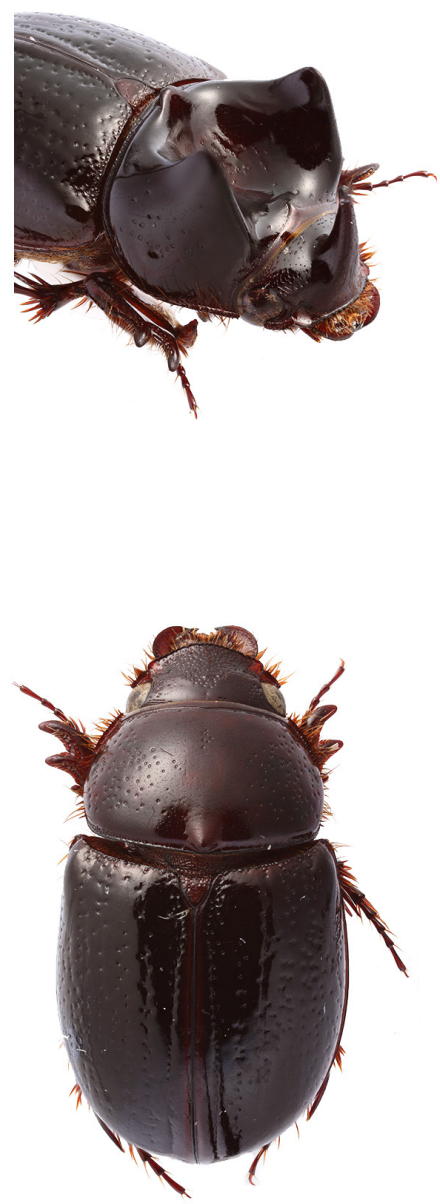

$\mathrm{D}-$

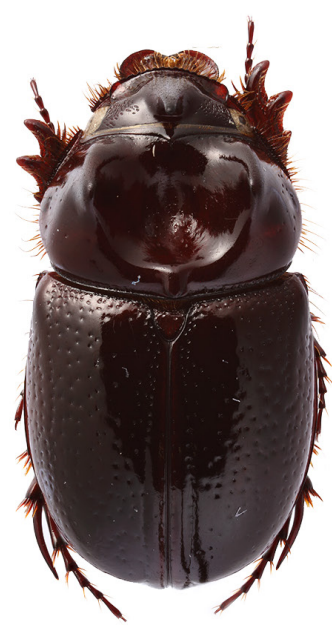

$\mathrm{B}-$
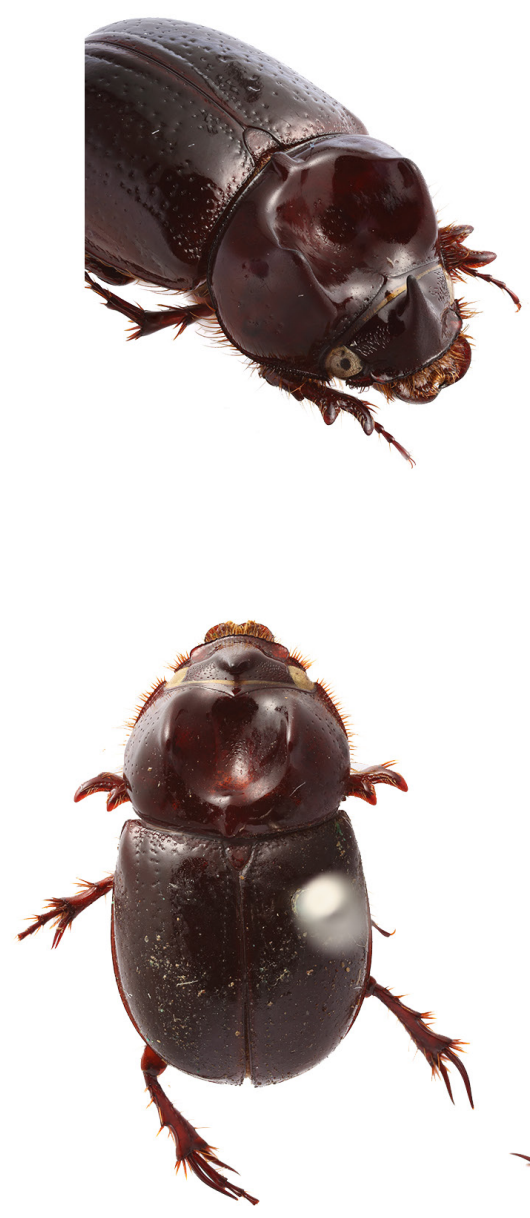

$\mathrm{E}-$

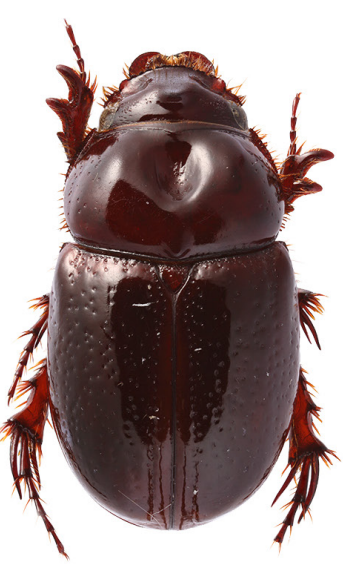

$\mathrm{C}-$

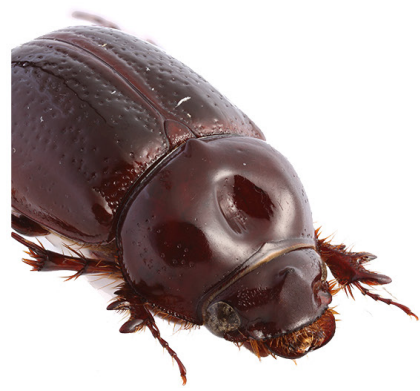

G

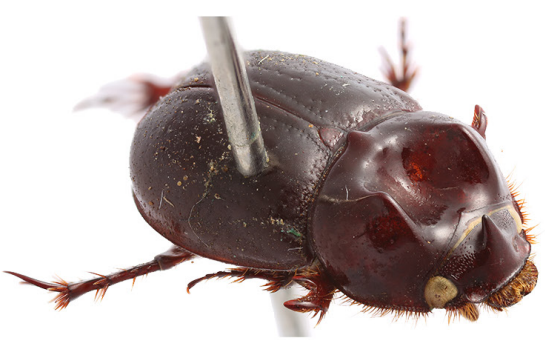

$\mathrm{F}$

Fig. 2. Orphnus mysoriensis Westwood, 1845. A-C. $\widehat{o}$ (NHMB). D. $q$ (NHMB). E-G. Lectotype of Orphnus detegens Walker, 1859, ô (BMNH). A-F. Habitus in dorsal view. G. Labels. Scale bars $=$ $1.0 \mathrm{~mm}$. 


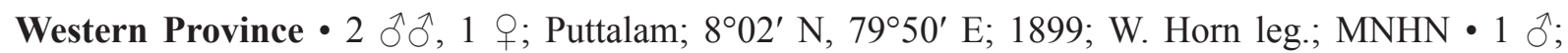
Rajakadaluwa; $7^{\circ} 39^{\prime}$ N, 7950' E; 22 Aug. 1953; F. Keiser leg.; NHMB. - Sabaragamuwa Province - 2 우우; Sabaragamuwa, Ratnapura; 645' N, 80³0' E; 20 Jan. 1970; Mussard, Besuchet, Lobl leg.; MCSN. - Southern Province • 3 q $q$; Bentota; $6^{\circ} 26^{\prime}$ N, 7960' E; 14 Aug. 1978; P. Cabella leg.; MCSN - 1 ${ }^{\lambda}$; same locality data as for preceding; 16 Aug. 1978; P. Cabella leg.; MCSN • 1 q; same locality data as for preceding; 20 Aug. 1978; P. Cabella leg.; MCSN・3 $\widehat{\jmath}, 5$ q $O$; same locality data as for preceding; 23 Mar. 1973; G. Zimmermann leg.; MNHB • 1 क; Matara; 557' N, 80³3' E; 20 Oct. 1953; F. Keiser leg.; NHMB. - Western Province • 1 q; Colombo; 656' N, 7951' E; MNHN • 1 ơ; same locality data as for preceding; MHNG $\bullet 1$; same locality data as for preceding; Feb. 1884; MNHB •

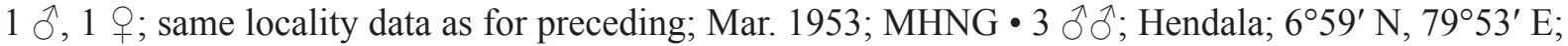

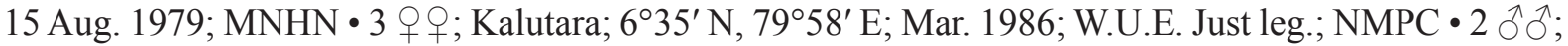
Kalutara Distr., Tebuwana; 6 $35^{\prime}$ N, 80 $03^{\prime}$ E; 13 Mar. 2000; S. Mahunka and L. Mahunka-Papp leg.;

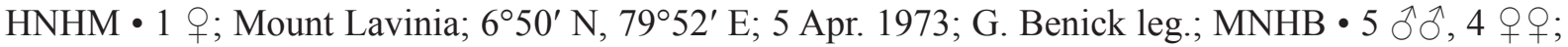
Wadduwa; $6^{\circ} 40^{\prime} \mathrm{N}, 79^{\circ} 56^{\prime} \mathrm{E}$; V. De Poll leg.; MNHN. - Sri Lanka (no exact locality) • 9 ๙ $^{\lambda}, 1$;

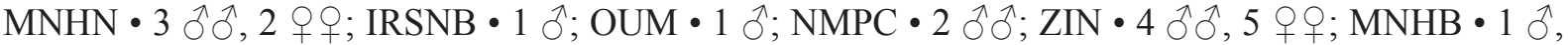
1 क; MHNG • 1 क; Diener leg.; HNHM • 3 qo+; Friederichs S.G. leg.; MNHB • 2 우; S. Niethner

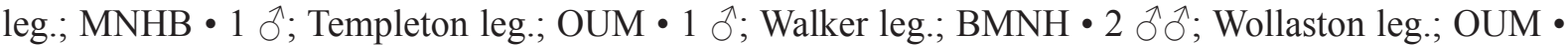

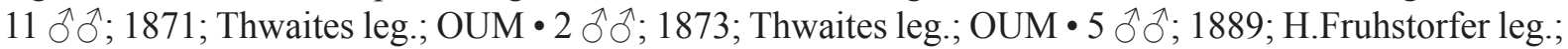
MNHN • 1 §̊; Mar. 1889; H. Fruhstorfer leg.; MNHN.

\section{Variation}

Body length of the examined specimens varied from 8.0 to $10.5 \mathrm{~mm}$ (males) and from 7.0 to $9.0 \mathrm{~mm}$ (females). Head and pronotum armature in males varied from well-developed with long lateral pronotal processes and frontoclypeal horn (Fig. 2A) to excavated pronotum with gibbosities aside of the excavation and frontoclypeal tubercle (Fig. 2C), with intermediate variants (Fig. 2B).

\section{Distribution}

The species is distributed rather widely on Sri Lanka except for the eastern part (Fig. 1H).

Orphnus medvedevi sp. nov. urn:lsid:zoobank.org:act:3F99F2E5-0FD6-4CE9-A3AC-53A7FBA4241D

Fig. 3

\section{Differential diagnosis}

Orphnus medvedevi sp. nov. is similar to O. mysoriensis in having the pronotum with more or less developed tubercle on base medially and endophallus with one group of spinules. It differs from the latter in shorter body (4.6-6.0 mm, as opposed to $8.0-10.0 \mathrm{~mm}$. in $O$. mysoriensis), spinules of endophallus as a compact cluster consisting of less than 10 spinules (as opposed to a rather dispersed group of more than 10 spinules in O. mysoriensis, Fig. 3G vs Fig. 1G), and tubercle on the base of pronotum always smooth (as opposed to having normally two punctures in $O$. mysoriensis).

\section{Etymology}

The new species is named after Gleb Sergeevich Medvedev (1931-2009), a Russian coleopterist.

\section{Type material}

\section{Holotype}

SRI LANKA • ○’; "Shri Lanka Vilpattu [Sri Lanka, Wilpattu] 7.10.1982 G. Medvedev”; ZIN. 
Paratypes

SRI LANKA • 2 + + ; "Shri Lanka Vilpattu [Sri Lanka, Wilpattu] 8.10.1982 G. Medvedev"; ZIN • 1 ○,,

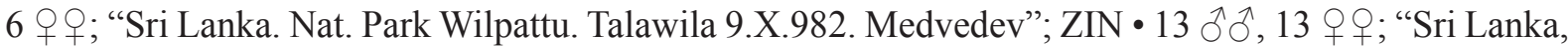
Wilpattu N.P. 17 km WNW entrance Tala Wila, 8.X.1982 V.F. Zaitzev leg.”; ZIN.

\section{Description}

Male, holotype (Fig. 3A, D-G)

BoDy. Length $6.0 \mathrm{~mm}$. Colour uniformly brown.

Clypeus. Wide, with convex anterior margin, rounded laterally, finely crenulate. Genae small, not protruding past eyes. Frontal suture indistinct. Clypeus with long, slender horn directed upwards and slightly curved backwards apically. Dorsal surface of head finely punctate. Labrum deeply sinuate in the middle, distinctly protruding past clypeus.

Pronotum. With rounded sides, about 1.5 times as wide as long, with deeply concave disc, conical lateral processes aside excavation, and smooth, rounded tubercle medially near base. Anterior angles acute; posterior angles rounded, indistinct in dorsal view. Pronotum bordered on anterior margin and base. Lateral margins with long, sparse, brown setae. Sides irregularly punctate with round punctures separated by $3-5$ puncture diameters.

Scutellum. Subtriangular, narrowly rounded apically, about $1 / 10$ length of elytra.

ELYTRA. About as long as wide, with distinct humeral humps, widest in middle, lateral margins slightly rounded in basal half. First (sutural) stria distinct, as feebly impressed groove with row of punctures. Other stria before humeral humps as rows of round setiferous punctures, separated by more than 3 their diameters except for base of elytra. Elytral intervals covered with minute punctures.

WINGs. Macropterous.

Legs. Protibiae with 3 outer teeth. Lateral margin basad of outer teeth not crenulate. Apical spur of protibia absent. Left protarsus absent. Middle and hind legs similar in shape; metafemora and metatibiae about $1 / 8$ as long as the mesofemora and mesotibiae. Mesotibia and metatibiae somewhat triangular with 2 apical spurs, inner margin almost straight, with 1 transverse keel. Upper spur of tibiae as long as two basal tarsomeres. Claws $1 / 3$ length of apical tarsomere. Femora almost impunctate.

ABDOMEN. Ventrally irregularly punctate, pubescent, with sparse, long setae. Abdominal sternite 8 medially shorter than sternites 4-7 combined. Pygidium invisible from above, with slightly truncate apex in caudal view. Plectrum triangular with rounded apex, wider than long.

Aedeagus. Parameres relatively short ( 0.5 length of phallobase), curved downwards, tapering apically, spear-shaped in dorsal view, with feebly visible lateral teeth (Fig. 3D-E). Endophallus with a compact cluster of 6 spinules (Fig. 3G).

\section{Female}

Female (Fig. 3H) differs from the male in having a relatively smaller pronotum without armature, frontoclypeus without process, and prothoracic spur present.

\section{Variation}

Body length of the paratypes varies from 5.9 to $4.6 \mathrm{~mm}$ (males) and 4.7 to $6.0 \mathrm{~mm}$ (females). Some of the paratypes have darker elytra. Head and pronotum armature in males paratypes varies from relatively 

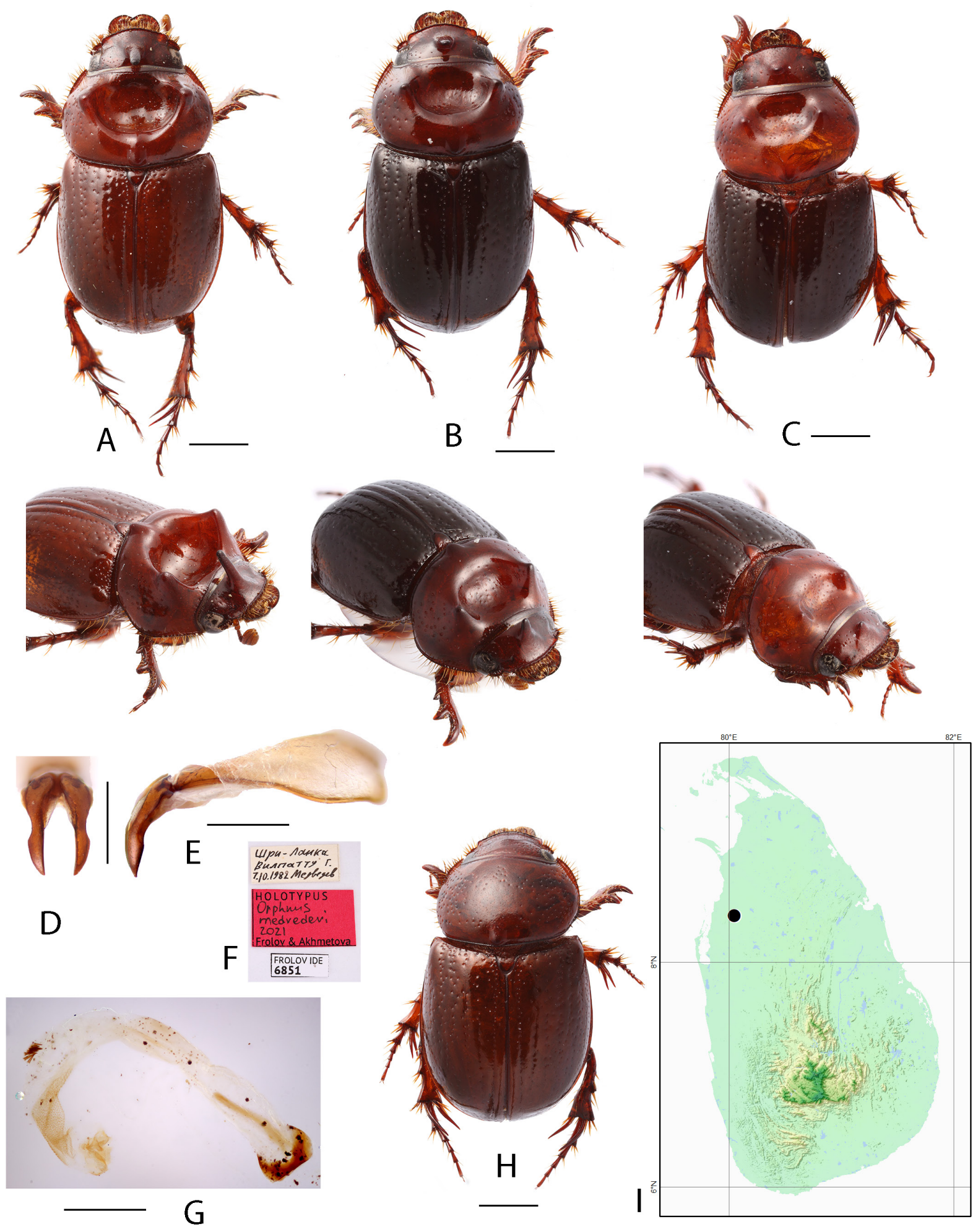

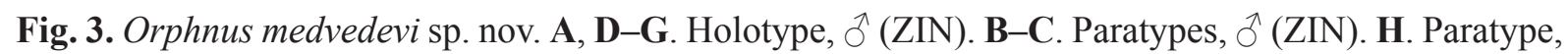
q $(\mathrm{ZIN}) . \mathbf{A}-\mathbf{C}, \mathbf{H}$. Habitus in dorsal view. D. Parameres in dorsal view. E. Aedeagus in lateral view. F. Labels. G. Endophallus. I. Distributional record map. Scale bars: A-C, H $=1.0 \mathrm{~mm}$; D-E, G = $0.5 \mathrm{~mm}$. 
well-developed, similar to that of the holotype, to excavated pronotum with gibbosities beside the excavation and frontoclypeal tubercle (Fig. 3C), with intermediate variants (Fig. 3B).

\section{Distribution}

The species is known from one locality in north-western Sri Lanka (Fig. 3I).

\section{Orphnus bicolor (Fabricius, 1801)}

Fig. 4

Scarabaeus bicolor Fabricius, 1801: 9.

Orphnus bicolor - MacLeay 1819: 119. — Westwood 1845: 176. — Lacordaire 1856: 130 (catalogue). — Gemminger \& Harold 1869: 1072 (catalogue). - Arrow 1912: 29 (catalogue). — Schmidt 1913: 79 (catalogue). — Frolov 2012: 793 (catalogue).

\section{Differential diagnosis}

Orphnus bicolor is similar to O. parvus in having the pronotum without tubercle on base medially and endophallus with a few groups of spinules. It differs from the latter in having the parameres in dorsal view with small but distinct notches basad of the lateral teeth (Fig. 4F), longer parameres (about 0.7 length of phallobase [Fig. 4E] as opposed to 0.5 length of phallobase in O. parvus [Fig. 5E]), and abdominal sternite 8 medially longer than sternites 4-7 combined (as opposed to sternite 8 medially as long as sternites 4-7 combined in $O$. parvus).

\section{Type material}

Lectotype (here designated, Fig. 4A-F)

INDIA - O; "TYPE / Ind. orient. Daldorff Mus. T. Lund Geotrupes bicolor F. / Lectotype Geotrupes bicolor F. A.Frolov des. 2016"; ZMUKG.

\section{Paralectotype}

INDIA・ 1 万े; “TYPE / Paralectotype Geotrupes bicolor F. A.Frolov des. 2016”; ZMUKG.

\section{Additional material examined}

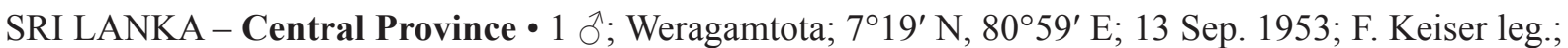

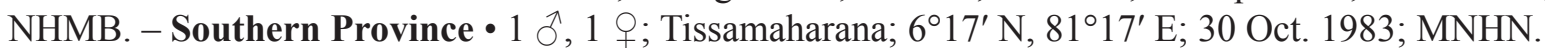

\section{Variation}

Body length of the examined specimens varies from 7.5 to $9.0 \mathrm{~mm}$ (males) and $8.6 \mathrm{~mm}$ (female).

\section{Distribution}

The species was described form "East India". In Sri Lanka, it is known from two rather distant localities in the centre and on the southern coast (Fig. 4I).

\section{Orphnus parvus (Wiedemann, 1823)}

Fig. 5

Geotrupes parvus Wiedemann, 1823: 6.

Orphnus nanus Westwood, 1845: 177 (synonymy by Arrow 1912).

Orphnus parvus - Gemminger \& Harold 1869: 1073 (catalogue). — Arrow 1912: 30 (catalogue). Schmidt 1913: 80 (catalogue). — Frolov 2012: 794 (catalogue). 


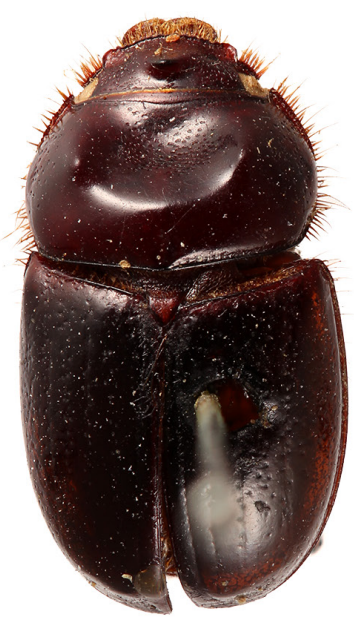

A -

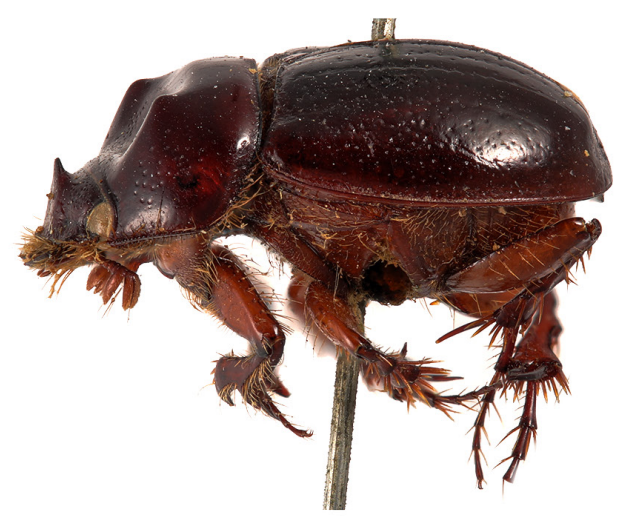

$\mathrm{B}-$

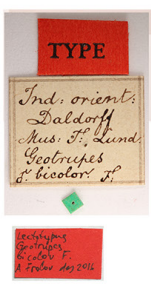

C

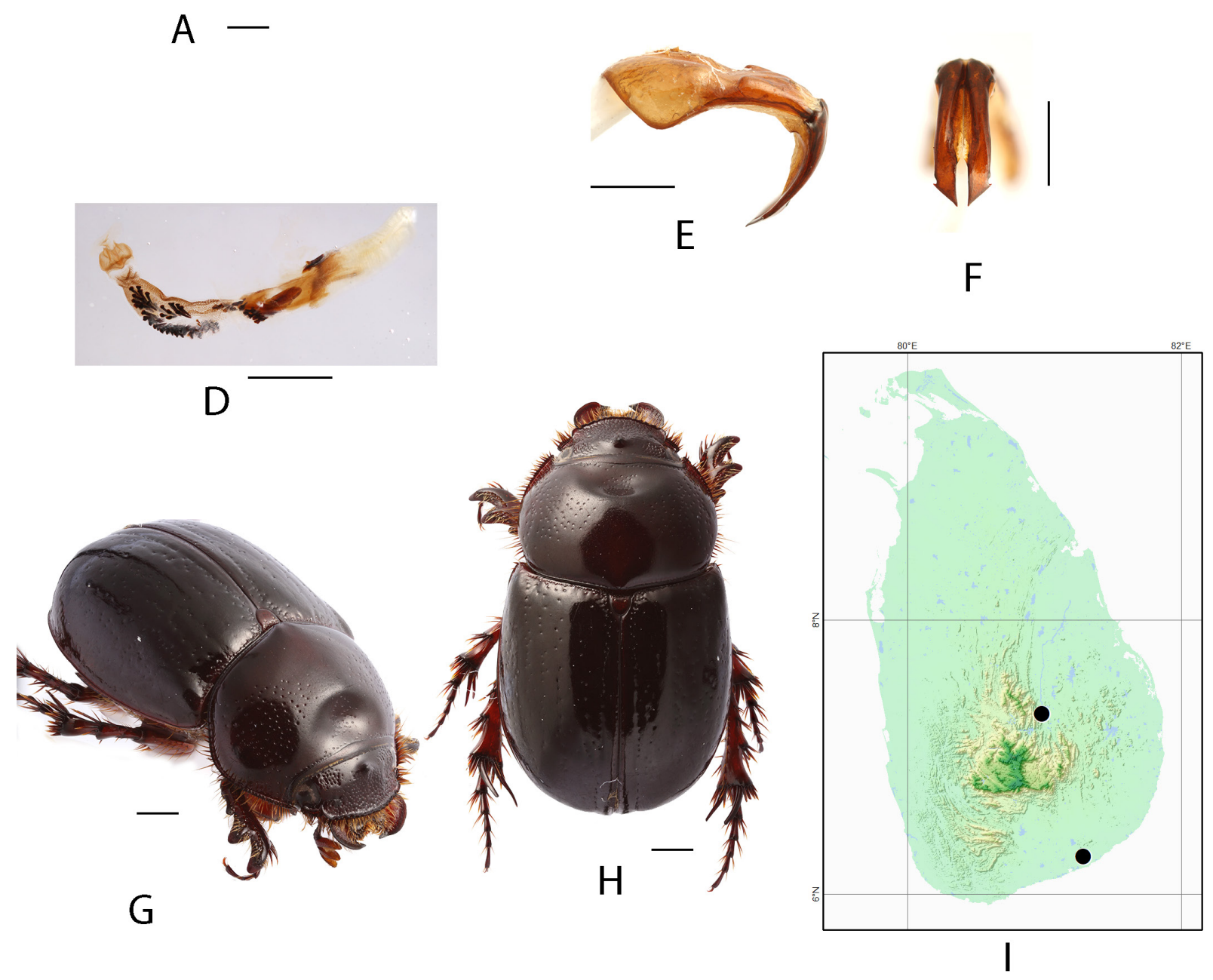

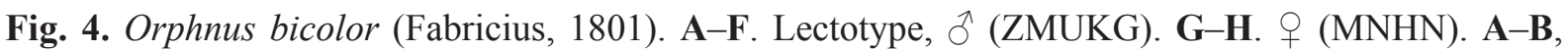
G-H. Habitus in dorsal view. C. Labels. D. Endophallus. E. Aedeagus in lateral view. F. Parameres in dorsal view. I. Distributional record map. Scale bars: A-B, G-H $=1.0 \mathrm{~mm}$; D-F $=0.5 \mathrm{~mm}$. 

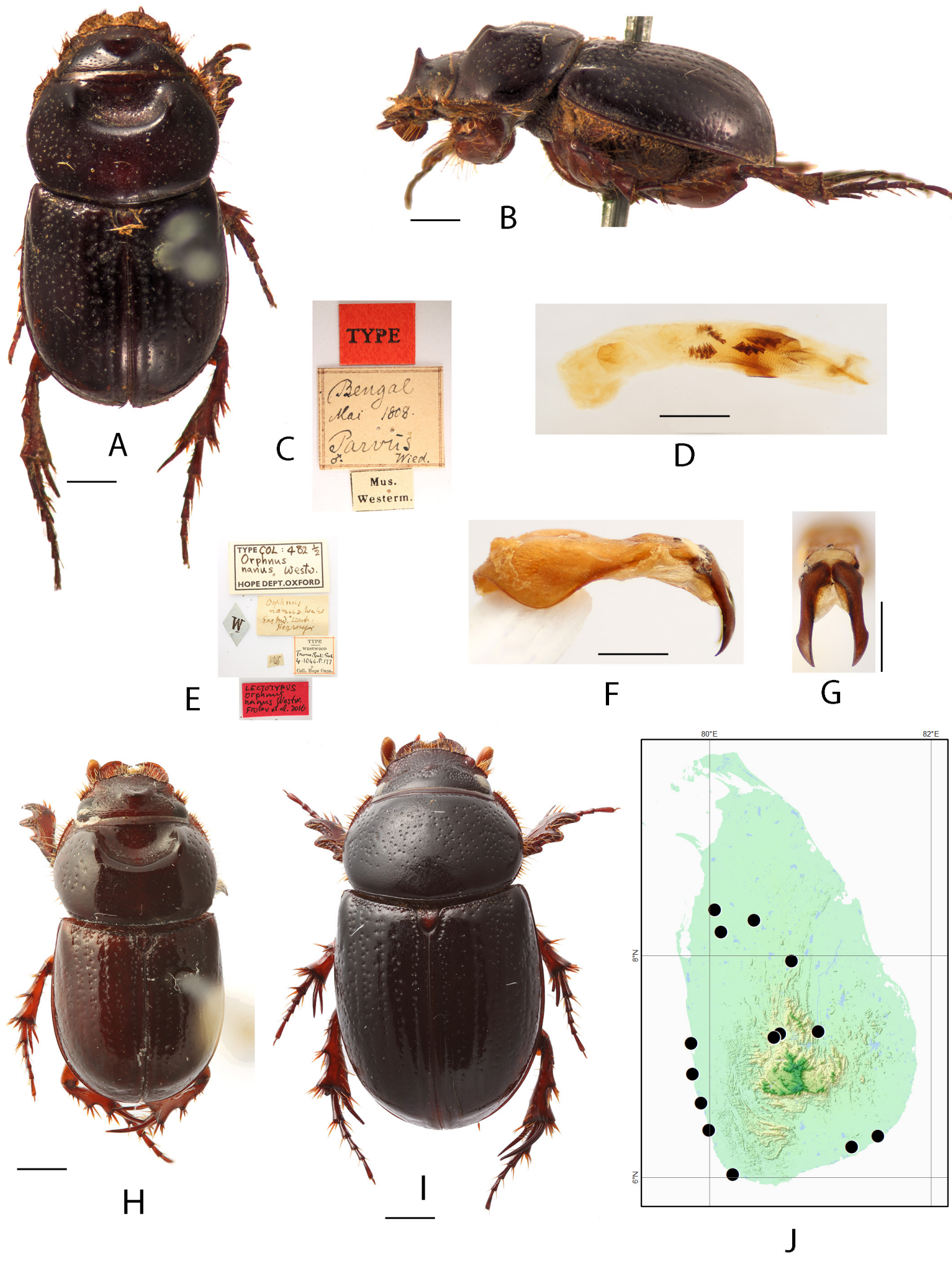

Fig. 5. Orphnus parvus (Wiedemann, 1823). A-C. Lectotype, $ð$ (ZMUKK). D-H. Lectotype of Orphnus nanus Westwood, 1845, ô (ZMUKK). I. o (MNHN). A-B, H-I. Habitus in dorsal view. C, E. Labels. D. Endophallus. F. Aedeagus in lateral view. G. Parameres in dorsal view. J. Distributional record map. Scale bars: A-B, $\mathrm{H}-\mathrm{I}=1.0 \mathrm{~mm}$; $\mathrm{D}, \mathrm{F}-\mathrm{G}=0.5 \mathrm{~mm}$. 


\section{Differential diagnosis}

Orphnus parvus is similar to O. bicolor in having the pronotum without a tubercle on base medially and endophallus with a few groups of spinules. It differs from the latter in having the parameres in dorsal view without notches basad of lateral teeth (Fig. 5G), shorter parameres (about 0.5 length of phallobase [Fig. 5E] as opposed to 0.7 length of phallobase in $O$. bicolor [Fig. 4E]), and abdominal sternite 8 medially as long as sternites 4-7 combined (as opposed to sternite 8 medially distinctly longer than sternites 4-7 combined in $O$. bicolor).

\section{Type material of Geotrupes parvus}

Lectotype (here designated, Fig. 5A-C)

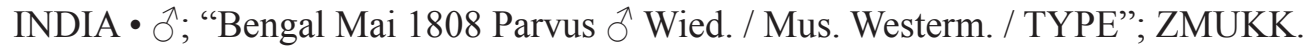

\section{Paralectotype}

INDIA • 1 §̊; "Mus. Westerm. / TYPE”; ZMUKK.

\section{Type material of Orphnus nanus}

Lectotype (here designated, Fig. 5D-H)

INDIA • 1 万; "TYPE COL : 482 1/2 Orphnus nanus Westw. HOPE DEPT.OXFORD / Orphnus nanus Westw East Ind [...] Hearsey / TYPE WESTWOOD Trans. Ent. Soc. 4.1846.P.177 Coll. Hope Oxon. / [...] / W / LECTOTYPUS Orphnus nanus Westw. Frolov et al. 2016"; ZMUKK.

\section{Paralectotype}

INDIA • 1 ô; “TYPE COL : 482 2/2 Orphnus nanus Westw. HOPE DEPT.OXFORD/TYPE WESTWOOD Trans. Ent. Soc. 4.1846.P.177 Coll. Hope Oxon. / Prof. Westwood's private collection purchased from Miss Swann 1895 Collected by Gen. Hearsey in India / [9...H] / Orphnus nanus Westw"; ZMUKK.

\section{Additional material examined}

SRI LANKA • Central Province $-2 \partial^{\lambda} \partial^{\lambda}$; Kandy; $7^{\circ} 18^{\prime} \mathrm{N}, 80^{\circ} 38^{\prime} \mathrm{E}$; MHNG 11 q; Peradenyia; $7^{\circ} 16^{\prime} \mathrm{N}$,

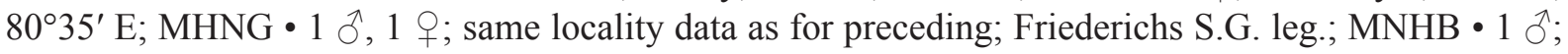
same locality data as for preceding; 3 Apr. 1907; O. John leg.; ZIN • 1 क ; Sigiriya; $7^{\circ} 57^{\prime} \mathrm{N}, 80^{\circ} 45^{\prime} \mathrm{E}$; Oct. 1977; MHNG • 2 우; Weragamtota; $7^{\circ} 19^{\prime}$ N, 8059' E; 13 Sep. 1953; F. Keiser leg.; NHMB. North Central Province • 1 क; Anuradhapura; $8^{\circ} 19^{\prime}$ N, $80^{\circ} 24^{\prime}$ E; Friederichs S.G. leg.; MNHB • 1 ○’; Kala Oya; $8^{\circ} 13^{\prime} \mathrm{N}, 80^{\circ} 06^{\prime} \mathrm{E}$; 7 Nov. 1983 ; MNHN 1 1 ; same locality data as for preceding; 8 Nov. 1983; MNHN • 1 क; Vilpattu Nat. Park, Talawila; $8^{\circ} 25^{\prime}$ N, 8003’ E; 9 Nov. 1983; G.S. Medvedev leg.; ZIN. - Southern Province 1 o ; 9 km SW of Yala; $6^{\circ} 22^{\prime}$ N, 81 ${ }^{\circ} 31^{\prime}$ E; 21 Oct. 1982; V.F. Zaitzev

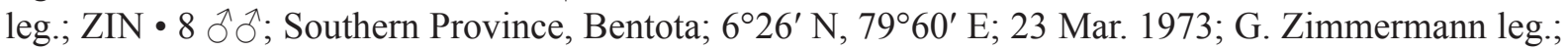

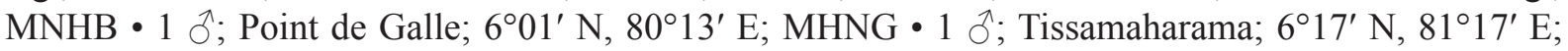

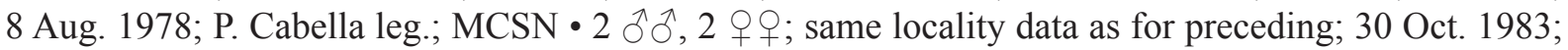
MNHN • 2 o $^{\prime}$; Yala; $6^{\circ} 22^{\prime} \mathrm{N}, 8^{\circ} 31^{\prime}$ E; 21 Oct. 1982; G.S. Medvedev leg.; ZIN. - Western Province

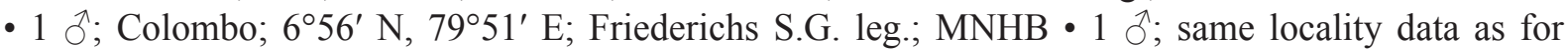

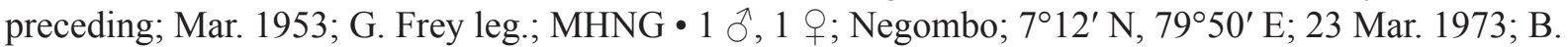
Huttler leg.; NMPC • 1 क; Wadduwa; $6^{\circ} 40^{\prime}$ N, $79^{\circ} 56^{\prime}$ E; V. De Poll leg.; MNHN. - Sri Lanka (no exact

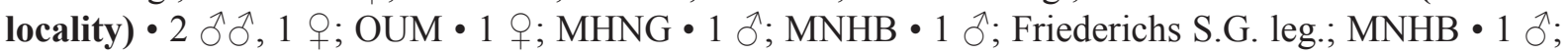
Parry leg.; IRSNB $\bullet 1$ § ; S. Niethner leg.; MNHB.

\section{Variation}

Body length of the examined specimens varies from 6.1 to $8.2 \mathrm{~mm}$ (males) and 6.0 to $7.5 \mathrm{~mm}$ (females). 


\section{Distribution}

The species is distributed rather widely throughout Sri Lanka except for the north-eastern part (Fig. 5J).

\section{Key to species of Orphnus from Sri Lanka (males)}

1. Pronotum with more or less developed tubercle on base medially (Figs 1A-B, 2A-C, 3A-C). Endophallus with 1 group of spinules (Figs 1G, 3G)

- Pronotum without tubercle on base medially (Figs 4A, H, 5A, H). Endophallus with more than 1 distinct group of spinules (Figs 4D, 5D)

2. Larger: body length $8.0-10.0 \mathrm{~mm}$. Spinules of endophallus as a rather dispersed group of more than 10 spinules (Fig. 1G). Tubercle on base of pronotum normally with 2 punctures; punctures may be close to each other or indistinct in some specimens .............Orphnus mysoriensis Westwood, 1845

- Smaller: body length 4.6-6.0 mm. Spinules of endophallus in a compact cluster consisting of less than 10 spinules (Fig. 3G). Tubercle on base of pronotum smooth ...... Orphnus medvedevi sp. nov.

3. Parameres in dorsal view with small but distinct notches basad of lateral teeth (Fig. 4F). Parameres longer, about 0.7 length of phallobase (Fig. 4E). Abdominal sternite 8 medially longer than sternites 4-7 combined

Orphnus bicolor (Fabricius, 1801)

- Parameres in dorsal view without notches basad of lateral teeth (Fig. 5G). Parameres shorter, about 0.5 length of phallobase (Fig. 5F). Abdominal sternite 8 medially as long as sternites 4-7 combined

Orphnus parvus (Wiedemann, 1823)

\section{Discussion}

Since the shape of aedeagi and internal sac armature were not utilized by the previous authors dealing with Asian Orphninae, we decided to re-examine the types of the two species described by Walker from Sri Lanka but later synonymised by Arrow (1912). Walker (1859a, 1859b) described two species of Orphnus, O. detegens and O. scitissimus. In the original description of the former, males and females are mentioned. However, only one specimen of the type series was found in the BMNH collection. This specimen (Fig. 2E-F) is a male designated here as the lectotype. It agrees with the original description of $O$. detegens and the type and other material of $O$. mysoriensis and therefore we can confirm synonymy proposed by Arrow (1912).

Despite every effort was made to trace the type (types) of $O$. scitissimus in the institutions that may house Walker's collection, we failed to find any specimens that could be considered as the types. The original description was apparently based on a female and fits the diagnosis of $O$. mysoriensis, although it is very brief and does not include diagnostic characters of this species. The size indicated $(8.5 \mathrm{~mm})$ agrees with $O$. mysoriensis but not with $O$. medvedevi sp. nov., which is significantly smaller. Therefore, we follow Arrow, who might have seen Walker's specimens, and consider of $O$. scitissimus as a synonym of $O$. mysoriensis.

Our results show that the fauna of the Orphninae of Sri Lanka, despite the relatively small size of the island, is comprised of four species and is comparable to the fauna of the whole mainland Asia which is inhabited by five species of Orphnus occurring from Northern India to Vietnam (Arrow 1912). Three of the four species also occur in India which can be explained by the relatively recent land connection of Sri Lanka and the Indian Peninsula.

\section{Acknowledgements}

We thank Maxwell Barclay (BMNH), Giulio Cuccodoro (MHNG), Alain Drumont (IRSNB), Jiř́ Hájek (NMPC), Bernd Jaeger (MNHB), Michael Kuhlmann (ZMUKG), Darren Mann (OUM), the 
late Otto Merkl (HNHM), Olivier Montreuil (MNHN), Roberto Poggi (MCSN), Alexey Solodovnikov (ZMUKK), and Eva Sprecher (NHMB) for providing access to the specimens and for help during our visits to their institutions. We are especially thankful to Maxwell Barclay, Darren Mann and Amoret Spooner (OUM), and Aidan O'Hanlon (National Museum of Ireland, Dublin) for their help in tracing Walker's types. Two anonymous reviewers provided valuable comments on the draft manuscript. The study was performed in the framework of the Russian State research project AAAA-A19-119020690101-6.

\section{References}

Arrow G.J. 1912. Pachypodinae, Pleocominae, Aclopinae, Glaphyrinae, Ochodaeinae, Orphninae, Idiostominae, Hybosorinae, Dynamopinae, Acanthocerinae, Troginae. In: Junk W. \& Schenkling S. (eds) Coleopterorum Catalogus 43: 1-66. W. Junk, Berlin.

Fabricius J.C. 1801. Systema Eleutheratorum secundum ordines, genera, species: adiectis synonymis, locis, observationibus, descriptionibus. Tomus I. Impensis Bibliopolii Academici novi. Kiel.

Frolov A.V. 2012. Diagnosis, classification, and phylogenetic relationships of the orphnine scarab beetles (Coleoptera, Scarabaeidae: Orphninae). Entomological Review 92: 782-797.

https://doi.org/10.1134/S0013873812070056

Frolov A.V., Montreuil O. \& Akhmetova L.A. 2016. Review of the Madagascan Orphninae (Coleoptera: Scarabaeidae) with a revision of the genus Triodontus Westwood. Zootaxa 4207: 1-93.

https://doi.org/10.11646/zootaxa.4207.1.1

Frolov A.V. \& Akhmetova L.A. \& Vaz-de-Mello F.Z. 2017. Revision of the mainland species of the Neotropical genus Aegidium Westwood (Coleoptera: Scarabaeidae: Orphninae). Journal of Natural History 51: 1035-1090. https://doi.org/10.1080/00222933.2017.1319519

Gemminger M. \& Harold E. 1869. Catalogus Coleopterorum hucusque descriptorum synonymicus et systematicus. Vol. 4 Scarabaeidae: 979-1346. E.H. Gummi, Munich.

https://doi.org/10.5962/bhl.title.9089

Khaustov A.A. \& Frolov A.V. 2018. A new species, new genus and new records of heterostigmatic mites (Acari: Heterostigmata) phoretic on scarab beetles of the subfamily Orphninae (Coleoptera: Scarabaeidae). Zootaxa 4514: 181-201. https://doi.org/10.11646/zootaxa.4514.2.3

Lacordaire T. 1856. Histoire naturelle des Insectes. Genera des Coléoptères ou exposé méthodique et critique de tous les genres proposés jusqu'ici dans cet ordre d'insectes. Tome troisème contenant les familles des pectinicorne et lamellicornes. Roret, Paris. https://doi.org/10.5962/bhl.title.8864

MacLeay W.S. 1819. Horae Entomologicae: or Essays on the Annulose Animals. Vol. 1 Part 1. S. Bagster, London. https://doi.org/10.5962/bhl.title.48636

Mittal I. 2005. Diversity and conservation status of dung beetles (Laparosticti: Scarabaeidae: Coleoptera) in North India. Bulletin of the National Institute of Ecology 15: 43-51.

Preudhomme de Borre A. 1886. Descriptions de deux espèces nouvelles du genre Aegidium Westwood suivies de la liste des Orphnides du Musée royal d'histoire naturelle de Belgique. Annales de la Société entomologique de Belgique 30: 24-26. Available from https://www.biodiversitylibrary.org/page/12278747 [accessed 15 Aug. 2021].

Schmidt A. 1913. Coleoptera. Lamellicornia. Fam. Scarabaeidae. Subfam. Aegialinae, Chironinae, Dynamopinae, Hybosorinae, Idiostominae, Ochodaeinae, Orphninae. Genera Insectorum 150. V. Verteneuil \& L. Desmet, Bruxelles. 
Walker F. 1859a. Characters of some apparently undescribed Ceylon insects. The Annals and Magazine of Natural History, Including Zoology, Botany and Geology Series 3 3: 50-56. Available from https://www.biodiversitylibrary.org/page/2317765 [accessed 25 Aug. 2021].

Walker F. 1859b. Characters of some apparently undescribed Ceylon insects. The Annals and Magazine of Natural History, Including Zoology, Botany and Geology Series 3 4: 217-224.

https://doi.org/10.1080/00222935908697111

Westwood J.O. 1845. On the lamellicorn beetles which possess exserted mandibles and labrum, and 10-jointed antennae. Transactions of the Entomological Society of London 4: 155-180.

https://doi.org/10.1111/j.1365-2311.1846.tb01350.x

Wiedemann C.R.W. 1823. Zweihundert neue Käfer von Java, Bengalen, und dem Vorgebirge der guten Hoffnung. Zoologisches Magazin Kiel 2: 1-133. Available from

https://www.biodiversitylibrary.org/page/14928532 [accessed 25 Aug. 2021].

Manuscript received: 26 April 2021

Manuscript accepted: 27 July 2021

Published on: 6 September 2021

Topic editor: Nesrine Akkari

Section editor: Max Barclay

Desk editor: Pepe Fernández

Printed versions of all papers are also deposited in the libraries of the institutes that are members of the EJT consortium: Muséum national d'histoire naturelle, Paris, France; Meise Botanic Garden, Belgium; Royal Museum for Central Africa, Tervuren, Belgium; Royal Belgian Institute of Natural Sciences, Brussels, Belgium; Natural History Museum of Denmark, Copenhagen, Denmark; Naturalis Biodiversity Center, Leiden, the Netherlands; Museo Nacional de Ciencias Naturales-CSIC, Madrid, Spain; Real Jardín Botánico de Madrid CSIC, Spain; Zoological Research Museum Alexander Koenig, Bonn, Germany; National Museum, Prague, Czech Republic. 